Article

\title{
Composition-controlled synthesis of platinum and palladium nanoalloys as highly active electrocatalysts for methanol oxidation
}

\author{
Haiqiang Zhao a, Weihong Qi a,b,*, Xinfeng Zhou a, Haofei Wu a, Yejun Li c \\ a School of Materials Science and Engineering, Central South University, Changsha 410083, Hunan, China \\ ${ }^{\mathrm{b}}$ Key Laboratory of Non-ferrous Materials Science and Engineering, Ministry of Education, Central South University, Changsha 410083, Hunan, China \\ c Hunan Key Laboratory of Super Microstructure and Ultrafast Process, School of Physics and Electronics, Central South University, Changsha 410083, \\ Hunan, China
}

\section{A R T I C L E I N F O}

\section{Article history:}

Received 20 September 2017

Accepted 27 December 2017

Published 5 February 2018

\section{Keywords:}

Platinum and palladium alloy nanoparticles

Composition and size control

Methanol oxidation

\begin{abstract}
A B S T R A C T
Platinum and palladium (PtPd) alloy nanoparticles (NPs) are excellent catalysts for direct methanol fuel cells. In this study, we developed PtPd alloy NPs through the co-reduction of $\mathrm{K}_{2} \mathrm{PtCl}_{4}$ and $\mathrm{Na}_{2} \mathrm{PdCl}_{4}$ in a polyol synthesis environment. During the reaction, the feed molar ratio of the two precursors was carried over to the final products, which have a narrow size distribution with a mean size of approximately $4 \mathrm{~nm}$. The catalytic activity for methanol oxidation reactions possible depends closely on the composition of as-prepared PtPd alloy NPs, and the NPs with a Pt atomic percentage of approximately $75 \%$ result in higher activity and stability with a mass specific activity that is 7 times greater than that of commercial Pt/C catalysts. The results indicate that through composition control, PtPd alloy NPs can improve the effectiveness of catalytic performance.
\end{abstract}

(C) 2018, Dalian Institute of Chemical Physics, Chinese Academy of Sciences. Published by Elsevier B.V. All rights reserved.

\section{Introduction}

Platinum nanoparticles (NPs) are key electrocatalysts that are used in industrial processes and commercial devices, particularly for direct methanol fuel cells (DMFCs), which are used as sustainable replacements for traditional fossil fuels [1-5]. DMFCs have unique physical and chemical properties as well as the ability to facilitate both oxidation and reduction reactions $[6,7]$. However, there are two major drawbacks of these catalysts: Pt is expensive and scarce, and Pt NPs are easily contaminated by the carbon monoxide (CO) that is generated as an intermediate species during methanol oxidation reactions (MORs) [8,9]. Therefore, it is necessary to improve catalytic performance while conserving Pt.

One way of overcoming these problems is to prepare Pt NPs with high active specific surface areas. By downsizing NPs, a high surface-to-volume ratio is achieved, thus, enhancing the rate of efficiency at which the catalysts utilize metals [10]. Also, adjusting specific facets, edges, corners, and defects of NPs so that they can provide more active reaction sites to optimize the catalytic properties [11,12]. Another major strategy for improving the catalytic activity of NPs is to combine Pt with another metallic element into bimetallic alloys. Recently, there have been reports on bimetallic Pt-M ( $\mathrm{M}=\mathrm{Pd}, \mathrm{Au}, \mathrm{Ag}, \mathrm{Ru}, \mathrm{Fe}$, $\mathrm{Co}, \mathrm{Ni}$, etc.) catalysts with increased electrocatalytic activity that also minimize the consumption of Pt [14-20]. For example, the DMFC performance increased in the order of Pt/C $<\mathrm{Pt}-\mathrm{Fe} / \mathrm{C}$ $<\mathrm{Pt}-\mathrm{Co} / \mathrm{C} \approx \mathrm{Pt}-\mathrm{Cr} / \mathrm{C}[20]$.

Due to its proximity to $\mathrm{Pt}$ in the periodic table, Pd is considered a prime candidate for building platinum and palladium (PtPd) bimetallic catalysts, which are less expensive than pure Pt catalysts and exhibit excellent catalytic performance [21,22].

\footnotetext{
* Corresponding author. Tel: +86-731-88879341; Fax: +86-731-88876692; E-mail: qiwh216@csu.edu.cn This work was supported by the National Natural Science Foundation of China (21373272).

DOI: 10.1016/S1872-2067(18)63020-7 | http://www.sciencedirect.com/science/journal/18722067 | Chin. J. Catal., Vol. 39, No. 2, February 2018
} 
Recent studies have indicated that PtPd alloy NPs may be useful as catalysts for the hydrogenation of aromatic hydrocarbons and for the electro-oxidation of small organic molecules (methanol, ethanol, etc.) with high sulfur [23] and CO tolerance [24] due to the bifunctional effect of NPs. In addition, the use of $\mathrm{Pd}$ instead of other metals such as $\mathrm{Cu}, \mathrm{Ag}$, Co, or Ni could also help minimize corrosion and loss of catalysts when said catalysts are used in an acidic environment such as proton-exchange membrane (PEM) fuel cells [25].

Over the past decade, many Pt-Pd bimetallic NPs with a rich variety of structures and shapes, such as core-shell structures, nanocages, and tetrahedra have been prepared [26-28]. Many methods for preparing bimetallic NPs have been developed, such as: co-chemical reduction, seed-mediated growth, electrochemical deposition, and galvanic replacement [29-32]. However, PtPd NPs synthesized from these methods lack either size or composition tunability over a wide range and are generally not suitable for composition-dependent catalytic studies.

In this study, ultrasmall PtPd alloy NPs with controls on sizes (4.0-7.0 nm) and compositions were developed. Monodisperse PtPd NPs were prepared via the co-reduction of $\mathrm{K}_{2} \mathrm{PtCl}_{4}$ and $\mathrm{Na}_{2} \mathrm{PdCl}_{4}$ with Poly (vinyl pyrrolidone) (PVP) in ethylene glycol (EG) solution. The PtPd NPs were active catalysts for MORs in an $\mathrm{H}_{2} \mathrm{SO}_{4}$ solution, and their activity was composition dependent. The PtPd alloy NPs with atomic Pt in 75\% showed higher activity and durability than commercial Pt/C catalyst, and its mass specific activity was 7 times greater than that of commercial Pt/C catalysts. This study indicate that through the composition control, these PtPd alloy NPs can serve as an excellent platform for studying catalysis optimization.

\section{Experimental}

\subsection{Chemicals}

Potassium tetrachloroplatinate (II) $\left(\mathrm{K}_{2} \mathrm{PtCl}_{4}, \mathrm{AR}\right)$, sodium tetrachloropalladate $\left(\mathrm{Na}_{2} \mathrm{PdCl}_{4}, \mathrm{AR}\right)$, ethylene glycol (EG, AR), and acetone and poly (vinyl pyrrolidone) (PVP, $M_{\mathrm{w}}=55,000$ ) were purchased from Aladdin (Shanghai, China). Vulcan XC-72R was received from Cabot (Boston, MA, USA) and 5\% Nafion was purchased from Sigma (Shanghai, China). All reagents were used without further purification. High-purity deionized water $(>18.4 \mathrm{M} \Omega \cdot \mathrm{cm})$ was produced using Millipore A10 Milli-Q (Darmstadt, Germany).

\subsection{Synthesis of PtPd NPs}

PtPd alloy NPs were synthesized using a polyol method, in which $\mathrm{Na}_{2} \mathrm{PdCl}_{4}$ and $\mathrm{K}_{2} \mathrm{PtCl}_{4}$ served as the metal precursors, while PVP and EG served as a stabilizer and strong reductant, respectively. PVP was also used as a weak reductant due to its hydroxy $(\mathrm{OH})$ end groups [33]. The process of synthesizing uniform PtPd alloy NPs is shown in Scheme 1. PVP (105 mg) was dissolved in EG (8 mL) and heated to $110^{\circ} \mathrm{C}$ in air under magnetic stirring. Meanwhile, $\mathrm{Na}_{2} \mathrm{PdCl}_{4}(28.5 \mathrm{mg}, 0.1 \mathrm{mmol})$ and $\mathrm{K}_{2} \mathrm{PtCl}_{4}$ (40.4 mg, $0.1 \mathrm{mmol}$ ) were co-dissolved in EG (3 $\mathrm{mL}$ ) at room temperature. The EG solution of $\mathrm{K}_{2} \mathrm{PtCl}_{4}$ and

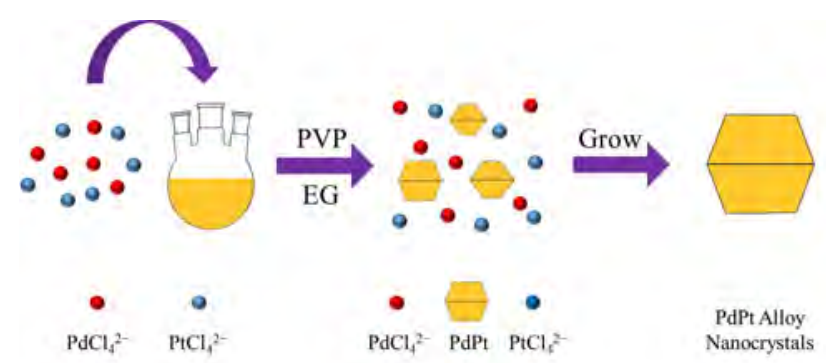

Scheme 1. Illustration of the synthetic pathway leading to the formation of PtPd alloy nanoparticles.

$\mathrm{Na}_{2} \mathrm{PdCl}_{4}$ was then added dropwise to the PVP solution. The reaction mixture was heated at $110{ }^{\circ} \mathrm{C}$ in air for $5 \mathrm{~h}$. After the mixture had cooled to room temperature, the PtPd NPs were centrifuged (13500 r/min, $30 \mathrm{~min}$ ) and washed three times with acetone to remove excess PVP and EG. The products were dispersed and preserved in ethanol. Finally, the as-prepared solution of PtPd NPs was dried in a vacuum oven at $70{ }^{\circ} \mathrm{C}$ for 8 h. The Pt/Pd atomic ratio was controlled by the Pt and Pd precursor ratios. The Pt1Pd3, Pt1Pd1 and Pt3Pd1 NPs were synthesized by using $\mathrm{K}_{2} \mathrm{PtCl}_{4}$ and $\mathrm{Na}_{2} \mathrm{PdCl}_{4}$ of $0.3 \mathrm{mmol} / 0.1 \mathrm{mmol}$, $0.1 \mathrm{mmol} / 0.1 \mathrm{mmol}$, and $0.1 \mathrm{mmol} / 0.3 \mathrm{mmol}$, respectively.

\subsection{Synthesis of PtPd/Vulcan XC-72R}

Two milligrams of PtPd NPs in acetone were mixed with 10 mg of carbon black (Vulcan XC-72R) and sonicated for $1 \mathrm{~h}$ to load all the NPs on carbon black. The PtPd/Vulcan XC-72R was separated by centrifugation ( $13500 \mathrm{r} / \mathrm{min}, 10 \mathrm{~min})$ and further purified twice by deionized water and dried in a vacuum oven at $70{ }^{\circ} \mathrm{C}$ for $8 \mathrm{~h}$. Finally, the PtPd/C was suspended in ethanol by sonication to form a PtPd/ Vulcan XC-72R suspension (2 $\mathrm{mg} / \mathrm{mL}$ ). The commercial Pt/C (E-TEK, 30\% Pt loading) was used without any treatment and was sonicated with ethanol to form a commercial Pt/C catalyst suspension ( $2 \mathrm{mg} / \mathrm{mL}$ ).

\subsection{Electrocatalytic evaluation}

All the electrochemical characterizations were carried out using a workstation (CHI660D, Chen Hua, Shanghai, China) and a three-electrode configuration with a glassy carbon (GC) electrode, a saturated calomel electrode (SCE), and a platinum foil as the working electrode, reference electrode and counter electrode, respectively. Prior to use, the GCE was carefully polished with alumina paste for $30 \mathrm{~s}$, thoroughly cleaned, and air-dried. For cyclic voltammogram (CV) measurements, $20 \mu \mathrm{L}$ of a catalyst dispersion was dropped onto the GC electrode and dried at room temperature. After solvent evaporation, $10 \mu \mathrm{L}$ of 0.05 $w t \%$ Nafion solution were dropped onto the surface of the GCE and air-dried. Cyclic voltammetry was first conducted at 50 $\mathrm{mV} / \mathrm{s}$ in $0.5 \mathrm{~mol} / \mathrm{L}_{2} \mathrm{SO}_{4}$ solution within the potential range -0.25 to $1.0 \mathrm{~V}$ (vs SCE). Before data collection, each catalyst modified electrode was cleaned and activated in the electrolyte solution for several cycles to ensure that a stable CV was obtained. The CVs were used to estimate the electrochemical active surface area (ECASA) of the catalyst by calculating the hy- 
drogen under potential desorption $\left(\mathrm{H}_{\text {upd }}\right)$ area of the catalyst. MOR measurements of the catalysts were conducted in a solution containing $0.5 \mathrm{~mol} / \mathrm{L} \mathrm{H}_{2} \mathrm{SO}_{4}$ and $0.5 \mathrm{~mol} / \mathrm{L} \mathrm{CH}_{3} \mathrm{OH}$ at a scan rate of $50 \mathrm{mV} / \mathrm{s}$ within the potential range 0 to $1.0 \mathrm{~V}$. Chronoamperometric (CA) curves were generated at $0.6 \mathrm{~V}$ in a solution containing $0.5 \mathrm{~mol} / \mathrm{L} \mathrm{H}_{2} \mathrm{SO}_{4}$ and $0.5 \mathrm{~mol} / \mathrm{L} \mathrm{CH}_{3} \mathrm{OH}$ for $1000 \mathrm{~s}$ to test the stabilities of various catalysts. The system was deaerated with $\mathrm{N}_{2}$ before the voltammetric behavior was monitored.

\subsection{Characterization}

Transmission electron microscopy (TEM) images of the PtPd NPs were obtained using a Tecnai G2F20 microscope operating at an accelerating voltage of $200 \mathrm{kV}$. High-resolution TEM (HRTEM) images were captured using a Titan G2 60-300 with an image corrector (point resolution $=80 \mathrm{pm}$ ) operating at an accelerating voltage of $300 \mathrm{kV}$. The samples for TEM and HRTEM were prepared by dropping the ethanol suspensions of the products on copper grids coated with amorphous carbon film. The structures of as-prepared products were characterized by X-ray diffraction (XRD) (Rigaku D/Max $2550 \mathrm{X}, \mathrm{Cu} K \alpha$ radiation, $\lambda=0.154178 \mathrm{~nm}$, Tokyo, Japan). The composition of PtPd/Vulcan XC-72R was determined by energy dispersive X-Ray spectroscopy (EDS, Quanta FEG250, 20 kV, FEI Company, Hillsboro, OR, USA).

\section{Results and discussion}

The reaction was conducted at a high rate of co-reduction by using EG as a reducing agent (i.e., the so-called polyol synthesis), with the feed molar ratio of $\mathrm{K}_{2} \mathrm{PtCl}_{4}$ to $\mathrm{Na}_{2} \mathrm{PdCl}_{4}$ kept at 1:1. TEM and HRTEM images of the typical product are shown in Fig. 1(a) and (b). The TEM studies and a size histogram of PtPd
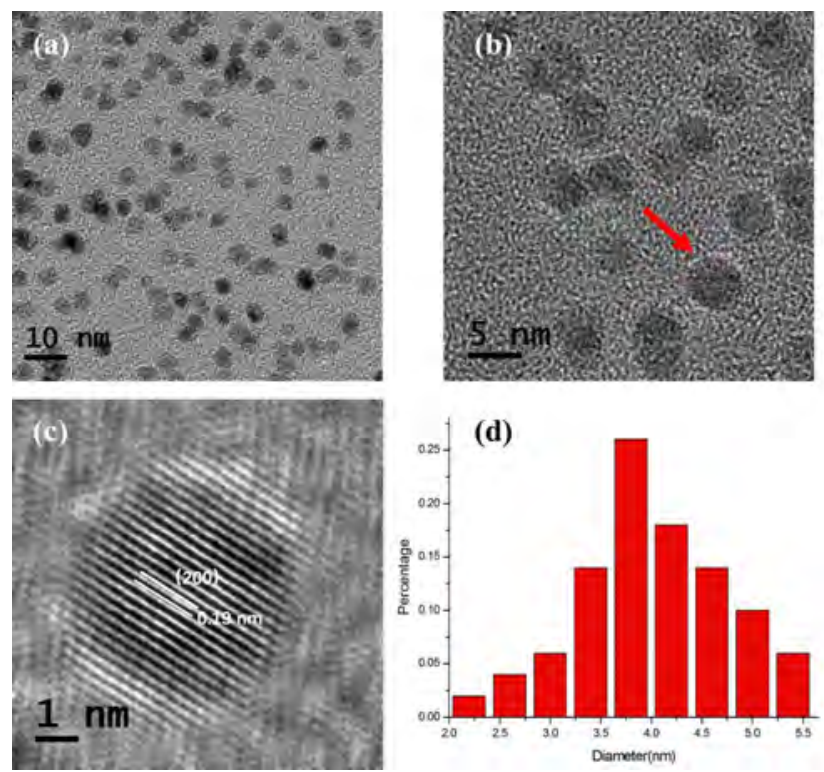

Fig. 1. (a) TEM images of PtPd alloy NPs with the feed molar ratio of $\mathrm{K}_{2} \mathrm{PtCl}_{4}$ to $\mathrm{Na}_{2} \mathrm{PdCl}_{4}$ at 1:1. (b) HRTEM image of as-prepared PtPd alloy NPs. (c) The corresponding FFT pattern of as-prepared PtPd NPs noted with red arrow in (b). (d) The corresponding size distribution of the samples.
NPs were obtained by counting 100 particles in Fig. 1(d). The results revealed that these products had a nearly octahedral profile and a narrow size distribution with a mean diameter of about $4 \mathrm{~nm}$. As-prepared monodisperse and uniform products depend critically on the reduction rate of the metal precursor. The synthesis process utilized EG as the reductant. The process of heating EG in air can generate GA (glycolaldehyde), a reductant that is stronger than EG [34]:

$$
2 \mathrm{HOCH}_{2} \mathrm{CH}_{2} \mathrm{OH}+\mathrm{O}_{2} \rightarrow 2 \mathrm{HOCH}_{2} \mathrm{CHO}+2 \mathrm{H}_{2}
$$

In polyol syntheses for noble metals, GA can be used as the primary reductant when the reaction temperature is within the range of 140 to $160{ }^{\circ} \mathrm{C}$. But EG as a reductant itself becomes more significant when synthesis is conducted at a lower temperature. This difference in the reductant at different reaction temperatures is vital because the preparation of $\mathrm{Pt}$ and $\mathrm{Pd}$ nanocrystals is usually carried out at lower temperatures. In practice, Pt and Pd precursors have proven to be more easily reduced, and it is unsurprising that EG itself is sufficient $[35,36]$. During synthesis, the reduction of Pd and Pt by EG at $70{ }^{\circ} \mathrm{C}$ resulted in the rapid generation of metal atoms and seeds that were greater in number in the product. At the same concentration of a precursor, the presence of more seeds means smaller sizes of the final products. In Fig. 1(c), a fast Fourier transform (FFT) pattern of as-prepared PtPd NPs is noted with a red arrow. In Fig. 1(b), the crystal fringe of as-prepared PtPd NPs measured to be $\sim 0.19 \mathrm{~nm}$, corresponding to the (200) interplanar spacing of the face-centered-cubic (fcc) alloy structure.

EDS analysis was used to determine the compositions of each sample (Fig. S1). The atomic ratio of $\mathrm{Pd}$ to $\mathrm{Pt}$ was 51.68:48.32, nearly $1: 1$. The result indicated that the composition of the products was consistent with the feed molar ratio, which is marked as Pt1Pd1.

The mole ratio of precursors is often a major influence on the morphology and structure of the product $[37,38]$. In this study, PtPd NPs were prepared in different compositions by adjusting the mole ratio of the precursors (Pt:Pd = 1:3 and 3:1). The TEM images in Fig. 2 indicate that the average nanocrystal size is not strongly influenced by the PtPd molar ratio of the precursors. In both reaction systems, the products were well dispersed and had nearly octahedral nanostructures with mean sizes of approximately 6.72 and $6.39 \mathrm{~nm}$. In addition, both samples were single-crystalline and showed high crystallinity,
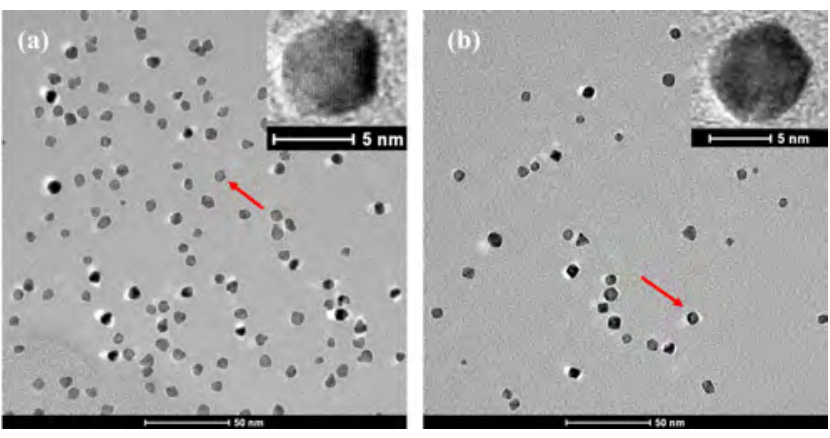

Fig. 2. TEM images of PtPd alloy NPs Pt1Pd3 (a) and Pt3Pd1 (b) respectively. The inserts correspond to HRTEM images of particles, which are marked with a red arrow. 
as confirmed by the corresponding HRTEM pattern. The EDS of the prepared products was analyzed with different feed ratios. In the results (Figs. S2 and S3), the atomic ratios of Pt to Pd in Pt1Pd3 and Pt3Pd1 were determined to be 27.1:72.9 and 74.3: 25.7 , respectively, very close to the feed molar ratios. The results can be attributed to the intrinsic physical properties of both Pt and Pd, which are as follows: (1) both possess fcc structures; (2) the difference of atomic radius between each one was $1.4 \%$ (the atomic radii of Pd and Pt are 1.37 and 1.39 $\AA$, respectively); (3) Pd and Pt have nearly similar electronegativities $(2.20$ and 2.28 , on the Pauling electronegativity scale, respectively) [39,40]; (4) the lattice mismatch of each one is only $0.77 \%$. These similarities enable them to easily form alloys with all compositions [41]. As a zero-order approximation, metal ions with more positive reduction potentials tend to be reduced at a faster rate than those with lower potentials. In general, metal ions with similar reduction potential are relatively easy to combinate to generate alloy NPs via co-reduction. $\mathrm{Pt}^{2+} / \mathrm{Pt}$ and $\mathrm{Pd}^{2+} / \mathrm{Pd}$, which have reduction potentials of +1.18 $\mathrm{V}$ and +0.9 (vs SHE), respectively, can be readily co-reduced nearly at the same time to form continuous PtPd alloyed NPs [42].

The XRD was used to characterize the structure of the as-prepared Pd and PtPd NPs, as shown in Fig. 3. All NPs show diffraction peaks corresponding to (111), (200) and (220) of the fcc structure.

The PtPd NPs were further characterized by their composition-dependent electrochemical behaviors. To minimize possible aggregation during the catalytic reaction and utilize the support effect, Vulcan XC-72R was used as the support. Vulcan $\mathrm{XC}-72 \mathrm{R}$ carbon is amorphous and widely used as the support material for the electrodes in DMFCs. 2 mg of PtPd NPs in acetone were mixed with $10 \mathrm{mg}$ of Vulcan XC-72R for $1 \mathrm{~h}$ and dried in a vacuum oven. Then the product was suspended in ethanol to form a $2 \mathrm{mg} / \mathrm{mL}$ PtPd/Vulcan XC-72R suspension. EDS results (Fig. S4) show that the Pt1Pd3 and Pt3Pd1 NPs loading on Vulcan XC-72R was $10.4 \%$ and $16.36 \%$, respectively. As shown in Fig. 4, the $\mathrm{CV}$ curves of Pt1Pd3/Vulcan XC-72R and Pt3Pd1/Vulcan XC-72R catalysts in $\mathrm{N}_{2}$-saturated $0.5 \mathrm{~mol} / \mathrm{L}$ $\mathrm{H}_{2} \mathrm{SO}_{4}$ were measured and compared with the curves of the commercial $\mathrm{Pt} / \mathrm{C}$ catalyst. In the test of $\mathrm{CV}$ curves, the potential

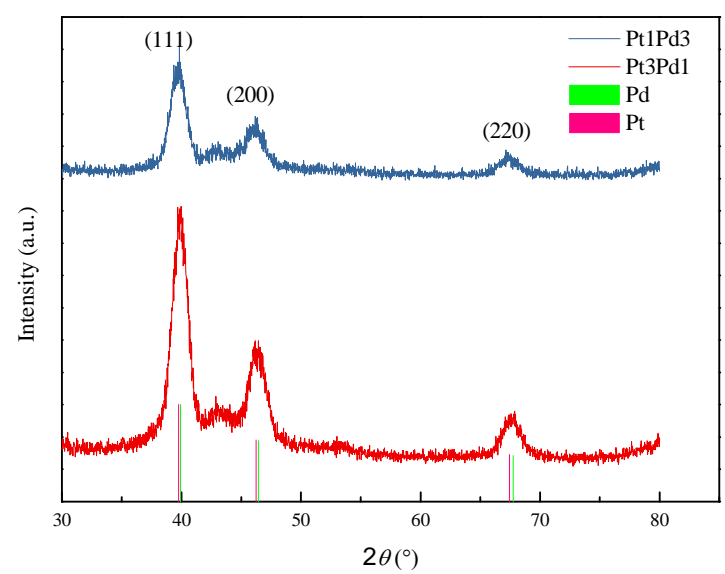

Fig. 3. XRD patterns of PtPd alloy NPs with different compositions.

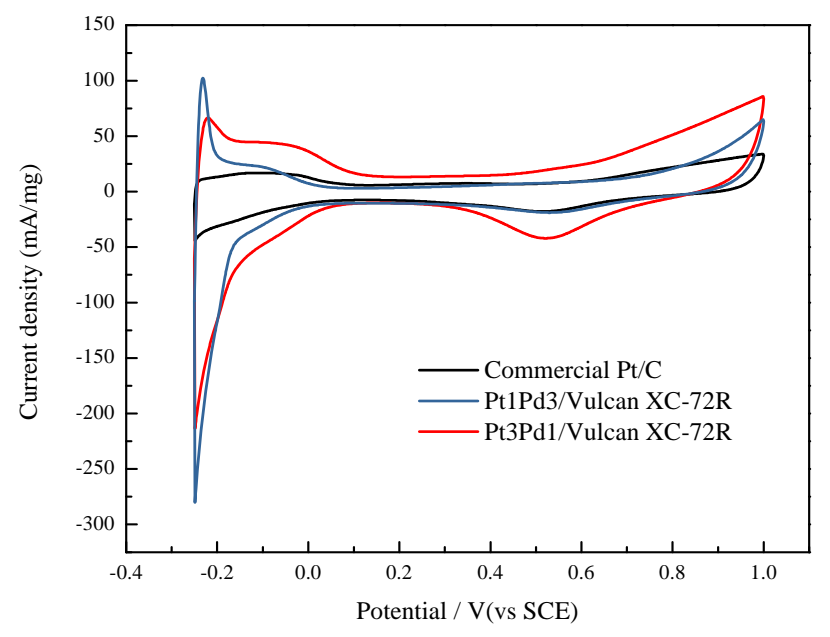

Fig. 4. $\mathrm{CV}$ curves of the commercial Pt/C, Pt1Pd3/Vulcan XC-72R and Pt3Pd1/Vulcan XC-72R catalysts obtained in $\mathrm{N}_{2}$-saturated $0.5 \mathrm{~mol} / \mathrm{L}$ $\mathrm{H}_{2} \mathrm{SO}_{4}$ with a scan rate of $50 \mathrm{mV} / \mathrm{s}$.

was scanned with a triangular wave from -0.25 to $1.0 \mathrm{~V}$. In the positive scanning direction, $\mathrm{CV}$ curves revealed that there was a large peak between -0.25 and $-0.12 \mathrm{~V}$, which suggested that the hydrogen experienced potential desorption ( $\mathrm{H}_{\text {upd }}$ ) on the NPs surface. The second peak indicates the formation of a hydroxide layer $\left(\mathrm{OH}_{\mathrm{ad}}\right)$ on the NPs surface. In the negative scanning direction, the two peaks can be attributed to NPs surface reduction and hydrogen adsorption, respectively.

The electrochemically active surface area (ECASA) can be calculated from the charge involved in the hydrogen adsorption/desorption processes using the following equations $[12,43]$.

$$
\text { ECASA }=\frac{Q_{\mathrm{S}}}{M \times 210 \mu \mathrm{C} / \mathrm{cm}^{2}}
$$

where $M$ is the loading of nanoparticles on the electrode, and the $Q_{s}$ is the surface charge that can be calculated from the $\mathrm{H}_{\text {upd }}$ area under the CV curve, as shown in Fig. S6 by

$$
Q_{\mathrm{S}}=\frac{\int I d E}{v}
$$

where $v$ is the scanning rate $(50 \mathrm{mV} / \mathrm{s})$ and, $\int I d E$ is the shaded area under the $\mathrm{CV}$ curve with the double layer current deducted. The ECASA of commercial Pt/C, Pt1Pd3/Vulcan XC-72R and Pt3Pd1/Vulcan XC-72R catalysts were 239.76, 604.85 and $891.76 \mathrm{~cm}^{2} / \mathrm{mg}$, respectively. The ECASA of Pt3Pd1/ Vulcan $\mathrm{XC}-72 \mathrm{R}$ was 3.72 times greater than that of the commercial $\mathrm{Pt} / \mathrm{C}$ catalyst, which indicated that catalytic activity was more efficient than the commercial catalyst.

The electrochemical performance of commercial Pt/C, Pt1Pd3/Vulcan XC-72R and Pt3Pd1/Vulcan XC-72R catalysts was tested for methanol oxidation, which is the heart of DMFC application in the anodic half-cell reaction. The data in Fig. 5 indicate that in the forward scan, methanol oxidation produced an anodic peak at around $0.7 \mathrm{~V}$. The increase in current density was likely due to the greater potential, which aids in the promotion of MOR. Then, the current density dropped as the NP surfaces were oxidized. In the backward scan, an anodic peak appears at around $0.4 \mathrm{~V}$. This anodic peak can be attributed to 

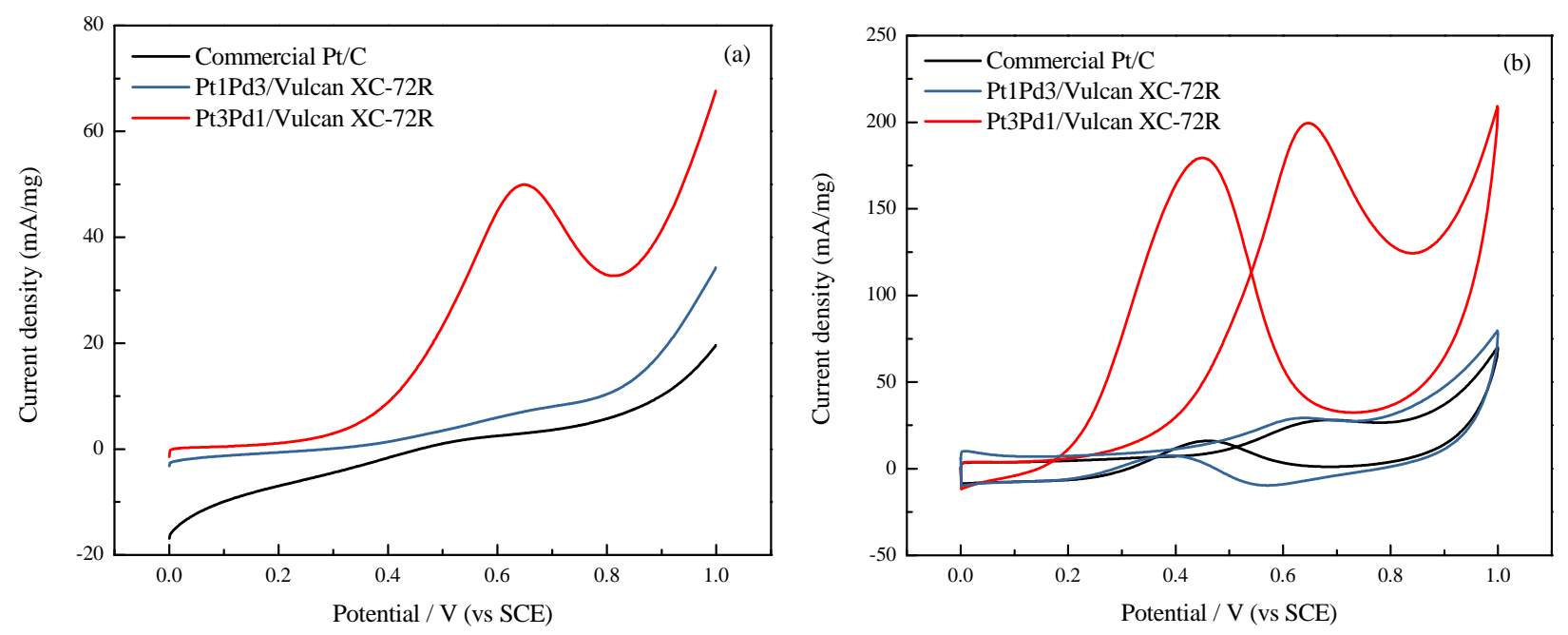

Fig. 5. CV (a) and LSV (b) curves of the commercial Pt/C, Pt1Pd3/Vulcan XC-72R and Pt3Pd1/Vulcan XC-72R catalysts obtained in $\mathrm{N}_{2}$-saturated 0.5 $\mathrm{mol} / \mathrm{L} \mathrm{H}_{2} \mathrm{SO}_{4}+0.5 \mathrm{~mol} / \mathrm{L} \mathrm{CH}_{3} \mathrm{OH}$ with a scan rate of $50 \mathrm{mV} / \mathrm{s}$.

the removal of the incompletely oxidized carbonaceous species formed in the forward scan. As the oxidized surface was reduced, the catalyst regained its original activity level, leading to a current density jump [44]. We then tabulated the data of the peak potential and peak current density of commercial $\mathrm{Pt} / \mathrm{C}$, Pt1Pd3/Vulcan XC-72R and Pt3Pd1/Vulcan XC-72R catalysts for methanol oxidation (Table S1). The statistical results showed that the Pt3Pd1/Vulcan XC-72R catalysts had a lower peak potential and the peak current density was 7 times greater than that of commercial Pt/C catalysts. The mass activities of commercial Pt/C, Pt1Pd3/Vulcan XC-72R, and Pt3Pd1/Vulcan XC-72R catalysts were $0.12,0.33$, and $0.03 \mathrm{~mA} / \mathrm{cm}^{2}$, respectively. These results indicated that the catalytic activity of Pt3Pd1/Vulcan XC-72R catalysts increased. The Pt1Pd3/Vulcan $\mathrm{XC}-72 \mathrm{R}$ catalysts have the lowest peak potential, and the peak current density is close to that of the commercial Pt/C catalysts. The ratio of the forward oxidation current peak ( $\mathrm{f}_{\mathrm{f}}$ ) to the reverse current peak $\left(I_{\mathrm{b}}\right), I_{\mathrm{f}} / I_{\mathrm{b}}$, denote the catalysts' tolerance to the poisoning species. A higher ratio indicated that a more effective removal rate of the poisoning species on the catalyst surface was taking place. As shown in Table S1, Pt1Pd3/Vulcan $\mathrm{XC}-72 \mathrm{R}$ has an $I_{\mathrm{f}} / I_{\mathrm{b}}$ ratio of 3.856 , higher than that of the commercial Pt/C (1.749), showing better catalyst tolerance. Liner sweep voltammograms (LSV) curves of the commercial Pt/C, Pt1Pd3/Vulcan XC-72R and Pt3Pd1/Vulcan XC-72R catalysts obtained in $\mathrm{N}_{2}$-saturated $0.5 \mathrm{~mol} / \mathrm{L} \mathrm{H}_{2} \mathrm{SO}_{4}+0.5 \mathrm{~mol} / \mathrm{L} \mathrm{CH}_{3} \mathrm{OH}$ are presented in Fig. 5(b). The results showed that the peak current for methanol oxidation of PtPd alloyed nanoparticles was higher than that of commercial Pt/C, suggesting highercatalytic activity of PtPd alloyed nanoparticles.

The bifunctional methanol oxidation mechanism can be used to elucidate the different MOR activities of the PtPd NPs with different compositions [45]. Pt is mainly responsible for the methanol dehydrogenation that results in the formation of $\mathrm{Pt}-\mathrm{CO}$, while Pd catalyzes the water dehydrogenation reactions to form $\mathrm{Pd}-\mathrm{OH}$. The reactions that occur between Pt-CO and $\mathrm{Pd}-\mathrm{OH}$ produce $\mathrm{CO}_{2}$ and regain the active metal surface. Be- cause of the shortage of $\mathrm{Pd}$, the water dehydrogenation reactions that occur on the surface of Pt would take place at a higher potential, slowing down all oxidation processes on pure platinum surfaces. The catalytic activity also decreases when the amount of Pd is excessive. This can be attributed to a lack of Pt for methanol dehydrogenation, as seen in the MOR catalysis of Pt1Pd3/Vulcan XC-72R catalysts [44].

Pt NPs catalysts are known to deteriorate quickly in the oxidizing acidic environment as demonstrated by the effectiveness of bimetallic NP solutions [46]. To further study the stability of the commercial Pt/C, Pt1Pd3/Vulcan XC-72R, and Pt3Pd1/Vulcan XC-72R catalysts, a chronoamperometry test was conducted in a solution of $0.5 \mathrm{~mol} / \mathrm{L} \mathrm{H}_{2} \mathrm{SO}_{4}$ and $0.5 \mathrm{~mol} / \mathrm{L}$ $\mathrm{CH}_{3} \mathrm{OH}$ for $1000 \mathrm{~s}$ at a fixed potential of $0.6 \mathrm{~V}$ (vs SCE), as shown in Fig. 6(a). The current density was very high in the initial solution because of the double-layer charging and the exposure of numerous available active sites. Then, the current density of all NPs decreased rapidly within a few seconds. Methanol oxidation resulted in the production of CO-like intermediates, such as $\mathrm{CO}$ and $\mathrm{CHO}$, which were adsorbed on the surface of active sites to prevent methanol's further oxidation [47]. The current density then maintained a steady state. Throughout the testing period, the current density of Pt3Pd1/Vulcan XC-72R catalysts remained higher than that of commercial Pt/C catalysts. The current density of Pt3Pd1/Vulcan XC-72R catalysts is $5.13 \mathrm{~mA} / \mathrm{mg}$ at $1000 \mathrm{~s}$, which is much higher than that of commercial Pt/C $(0.41$ $\mathrm{mA} / \mathrm{mg}$ at $1000 \mathrm{~s}$ ). Thus, the chronoamperometric i-t curves indicated that Pt3Pd1/Vulcan XC-72R catalysts were more resistant to poisoning by CO-like intermediates and were more stable. Here, the Pt3Pd1/Vulcan XC-72R was utilized as a typical catalyst for the observation of changes in morphology and composition of the catalysts due to the greater efficiency of its catalytic performance and durability in the MOR tests. Fig. 6(b) shows that the morphology of Pt3Pd1/Vulcan XC-72R remained unchanged after the i-t test for 1000 s, as does its composition (Fig. S5). 

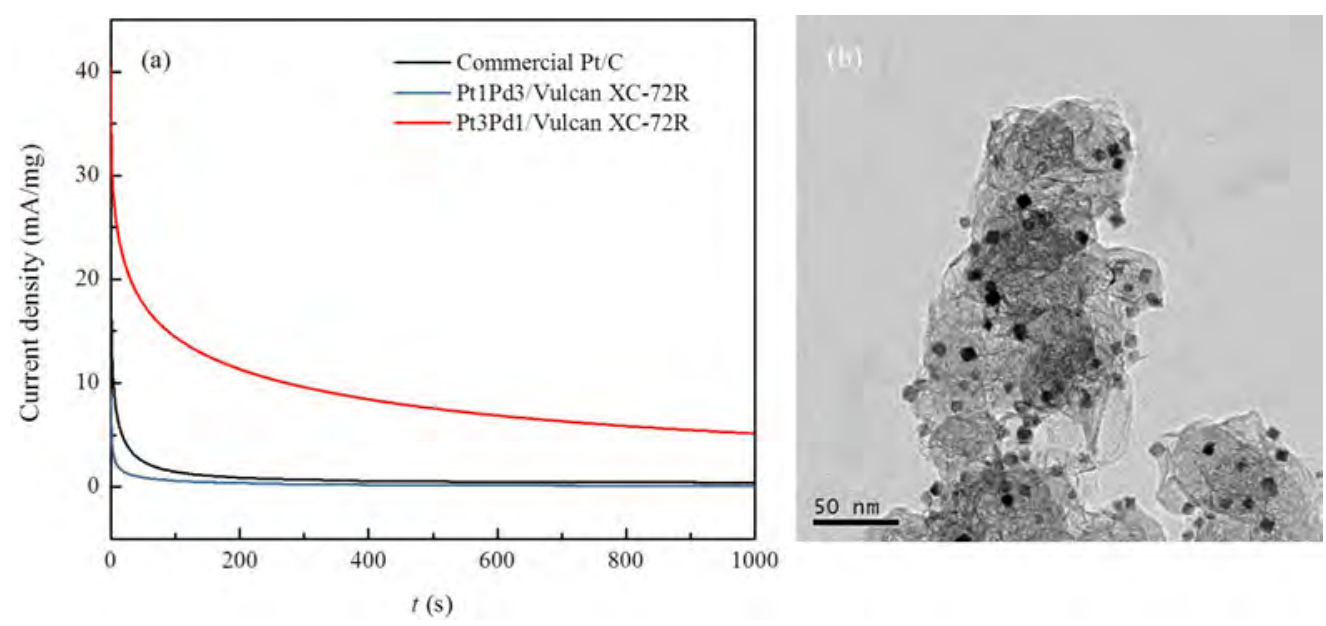

Fig. 6. (a) Chronoamperometric i-t curves of the commercial Pt/C, Pt1Pd3/Vulcan XC-72R, and Pt3Pd1/Vulcan XC-72R catalysts obtained in $\mathrm{N}_{2}$-saturated $0.5 \mathrm{~mol} / \mathrm{L} \mathrm{H}_{2} \mathrm{SO}_{4}+0.5 \mathrm{~mol} / \mathrm{L} \mathrm{CH}_{3} \mathrm{OH}$ at $0.6 \mathrm{~V}$. (b) The morphology of the Pt3Pd1/Vulcan XC-72R catalyst after the stability test.

\section{Conclusions}

This study was conducted to investigate a more cost effective and simple way to synthesize the composition-controlled PtPd NPs by adjusting the molar ratio of metal precursors. The strong reductive reactions that occurred during the polyol synthesis process allowed for the size of PtPd NPs to be controlled in a narrow distribution with a mean size of around 4 $\mathrm{nm}$. Three types of PtPd NPs catalysts were synthesized with different compositions, i.e. Pt1Pd3, Pt1Pd1, and Pt3Pd1. These NPs were supported on Vulcan XC-72R to evaluate the electrochemical performance for methanol oxidation. Among these NPs, Pt3Pd1/Vulcan XC-72R catalysts exhibited both excellent catalytic activity and stability of electrocatalytic performances. These improvements were due to the modified function of $\mathrm{Pd}$ atoms that underwent water dehydrogenation. This study indicates that, through composition control, these PtPd alloy NPs can serve as an excellent platform for studying catalysis optimization.

\section{Conflict of Interest}

The authors declare that they have no conflict of interest.

\section{References}

[1] W. Y. Wang, D. S. Wang, X. W. Liu, Q. Peng, Y. D. Li, Chem. Commun., 2013, 49, 2903-2905.

[2] B. H. Wu, N. F. Zheng, G. Fu, Chem. Commun., 2011, 47, 1039.

[3] J. J. Lv, J. N. Zheng, S. S. Li, L. L. Chen, A. J. Wang, J. J. Feng, J. Mater. Chem. A, 2014, 2, 4384-4390.

[4] B. H. Zhang, Y. G. Xue, H. Sun, A. Jiang, Z. B. Li, J. C. Hao, RSC Advances, 2016, 6, 56083-56090.

[5] L. N. Zhou, X. T. Zhang, Z. H. Wang, S. J Guo, Y. J. Li, Chem. Commun., 2016, 52, 12737-12740.

[6] S. Mourdikoudis, M. Chirea, T. Altantzis, I. Pastoriza-Santos, J. Perez-Juste, F. Silva, S. Bals, L. M. Liz-Marzan, Nanoscale, 2013, 5, 4776-4784.

[7] A. C. Chen, P. Holt-Hindle, Chem. Rev., 2010, 110, 3767-3804.
[8] R. Adzic, J. Lipkowski, P. Ross, Electrocatalysis, 1998, 197-241.

[9] A. B. Anderson, Electrochimi. Acta, 2002, 47, 3759-3763.

[10] W. H. Ji, W. H. Qi, S. S. Tang, H. C. Peng, S. Q. Li, Nanomaterials, 2015, 5, 2203-2211.

[11] K.M. Bratlie, H. Lee, K. Komvopoulos, P. D. Yang, G. A. Somorjai, Nano Lett., 2007, 7, 3097-3101.

[12] C. Wang, H. Daimon, T. Onodera, T. Koda, S. Sun, Angew. Chem. Int. Ed., 2008, 47, 3588-3591.

[13] W. H, Qi, Acc. Chem. Res., 2016, 49, 1587-1595.

[14] D. Xu, Z. P. Liu, H. Z. Yang, Q. S. Liu, J. Zhang, J. Y. Fang, S. Z. Zou, K. Sun, Angew. Chem. Int. Ed., 2009, 48, 4217-4221.

[15] J. Zhang, J. Y. Fang, J. Am. Chem. Soc., 2009, 131, 18543-18547.

[16] D. S. Wang, Q. Peng, Y. D. Li, Nano Res., 2010, 3, 574-580.

[17] J. Kim, Y. Lee, S. Sun, J. Am. Chem. Soc., 2010, 132, 4996-4997.

[18] Y. J. Kang, C. B. Murray, J. Am. Chem. Soc., 2010, 132, 7568-7569.

[19] V. R. Stamenkovic, B. S. Mun, M. Arenz, K. J. J. Mayrhofer, C. A. Lucas, G. F. Wang, P. N. Ross, N. M. Markovic, Nat. Mater., 2007, 6, 241-247.

[20] C. Venkateswara Rao, B. Viswanathan, J. Phys. Chem. C, 2009, $113,18907-18913$.

[21] F. Kadirgan, S. Beyhan, T. Atilan, Int. J. Hydrogen Energy, 2009, 34, 4312-4320.

[22] Q. Yuan, Z. Y. Zhou, J. Zhuang, X. Wang, Chem. Commun., 2010, 46, 1491-1493.

[23] H. Yasuda, N. Matsubayashi, T. Sato, Y. Yoshimura, Cataly. Lett., 1998, 54, 23-27.

[24] E. Antolini, Energy Environ. Sci., 2009, 2, 915-931.

[25] V. R. Stamenkovic, B. S. Fowler, B. S. Mun, G. F. Wang, P. N. Ross, C. A. Lucas, N. M. Marković, Science, 2007, 315, 493-497.

[26] H. Ataee-Esfahani, M. Imura, Y. Yamauchi, Angew. Chem. Int. Ed., 2013, 125, 13856-13860.

[27] L. Wang, Y. Yamauchi, J. Am. Chem. Soc., 2013, 135, 16762-16765.

[28] A. X. Yin, X. Q. Min, Y. W. Zhang, C. H. Yan, J. Am. Chem. Soc., 2011, $133,3816-3819$.

[29] W. Liu, P. Rodriguez, L. Borchardt, A. Foelske, J. Yuan, A. K. Herrmann, D. Geiger, Z. K. Zheng, S. Kaskel, N. Gaponik, R. Kötz, T. J. Schmidt, A. Eychmüller, Angew. Chem. Int. Ed., 2013, 52, 9849-9852.

[30] B. Lim, M. Jiang, P. H. C. Camargo, E. C. Cho, J. Tao, X. M. Lu, Y. M. Zhu, Y. N. Xia, Science, 2009, 324, 1302-1305.

[31] I. Choi, S. H. Ahn, J. J. Kim, O. J. Kwon, Appl. Catal. B, 2011, 102, 


\title{
Graphical Abstract
}

Chin. J. Catal., 2018, 39: 342-349 doi: 10.1016/S1872-2067(18)63020-7

\section{Composition-controlled synthesis of platinum and palladium nanoalloys as highly active electrocatalysts for methanol oxidation}

Haiqiang Zhao, Weihong Qi *, Xinfeng Zhou, Haofei Wu, Yejun Li Central South University

A composition-controlled synthesis of PtPd alloy nanoparticles via the co-reduction method was observed. The nanoparticles with $75 \%$ Pt exhibited superior activity and stability, and their mass specific activity was 7 times greater than that of commercial Pt/C catalysts.

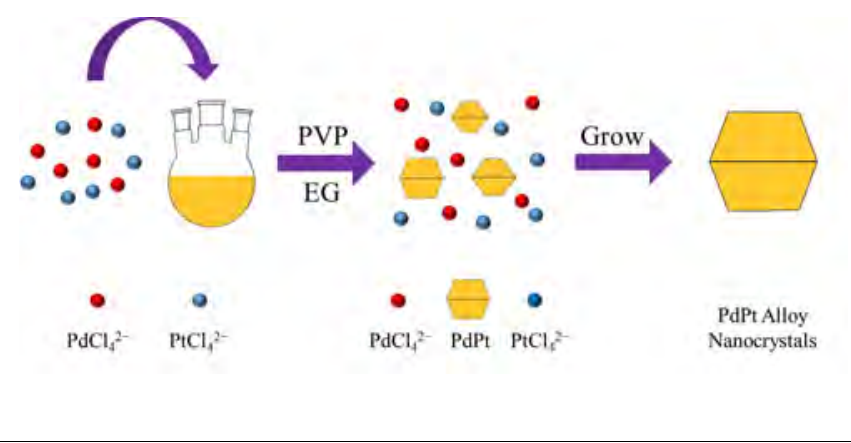

Yang, J. Am. Chem. Soc., 2008, 130, 13818-13819.

608-613.

[32] C. Koenigsmann, A. C. Santulli, K. Gong, M. B. Vukmirovic, W. P. Zhou, E. Sutter, S. S. Wong, R. R. Adzic, J. Am. Chem. Soc., 2011, 133, 9783-9795.

[33] I. Washio, Y. J. Xiong, Y. D. Yin, Y. N. Xia, Adv. Mater., 2006, 18, 1745-1749.

[34] S. E. Skrabalak, B. J. Wiley, M. Kim, E.V. Formo, Y. N. Xia, Nano Lett., 2008, 8, 2077-2081.

[35] S. E. Skrabalak, J. Y. Chen, Y. G. Sun, X. M. Lu, L. Au, C.M. Cobley, Y. N. Xia, Acc. Chem. Res., 2008, 41, 1587-1595.

[36] Y. J. Xiong, H. G. Cai, B. J. Wiley, J. G. Wang, M. J. Kim, Y. N. Xia, J. Am. Chem. Soc., 2007, 129, 3665-3675.

[37] A. Mohanty, N. Garg, R. C. Jin, Angew. Chem., 2010, 49, 4962-4966.

[38] B. Neppolian, V. Sáez, J. González-García, F. Grieser, R. Gómez, M. Ashokkumar, J. Solid State Electrochem., 2014, 18, 3163-3171.

[39] S. Chen, P. J. Ferreira, W. C. Sheng, N. Yabuuchi, L. F. Allard, S. H.
[40] S. I. Sanchez, M. W. Small, J. M. Zuo, R. G. Nuzzo, J. Am. Chem. Soc., 2009, 131, 8683-8689.

[41] F. R. De. Boer, R. Boom, W. C. M. Mattens, A. R. Miedema, A. K. Niessen, in Metals: Transition Metal Alloys, 1988.

[42] K. D. Gilroy, A. Ruditskiy, H. C. Peng, D. Qin, Y. N. Xia, Chem Rev., 2016, 116, 10414-10472.

[43] M. Watanabe, M. Tomikawa, S. Motoo, J. Electroanal. Chem. Interface., 1985, 195, 81-93.

[44] Y. Liu, M. Chi, V. Mazumder, K. L. More, S. Soled, J. D. Henao, S. H. Sun, Chem. Mater., 2011, 23, 4199-4203.

[45] C. R. Anthony, L. McElwee-White, J. Am. Chem. Soc., 2006, 921, 130-142.

[46] H. A. Gasteiger, S. S. Kocha, B. Sompalli, F. T. Wagner, Appl. Catal. $B, 2005,56,9-35$.

[47] F. Liu, J. Y. Lee, W. J. Zhou, Small, 2006, 2, 121-128.

\section{高活性甲醇氧化电催化剂Pt-Pd纳米合金的组分可控合成}

\author{
赵海强 ${ }^{\mathrm{a}}$, 齐卫宏 ${ }^{\mathrm{a}, \mathrm{b},{ }^{*}}$, 周金峰 ${ }^{\mathrm{a}}$, 吴影斐 ${ }^{\mathrm{a}}$, 李业军 $^{\mathrm{c}}$ \\ a中南大学材料科学与工程学院, 湖南长沙 410083 \\ ${ }^{\mathrm{b}}$ 中南大学教育部有色金属材料科学与工程重点实验室, 湖南长沙 410083 \\ c中南大学物理与电子学院先进材料超微结构与超快过程研究重点实验室, 湖南长沙410083
}

摘要: Pt纳米粒子由于其本身独特的物理、化学性质以及能够同时促进氧化和还原反应,在工业生产和商业设备中(尤其在 直接甲醇燃料电池中)广泛用作重要的电催化剂. 然而, Pt作为贵金属在自然界中的含量极其稀少, 价格昂贵; 另外, 甲醇氧 化反应中产生的中间产物CO很容易市Pt纳米粒子中毒而失活. 因此,迫切需要一种Pt用量少, 催化性能高的材料.

一制备高活性比表面积的Pt纳米颗粒, 可以有效提高Pt利用率. 另外, 调控纳米粒子使其裸露特定的晶面、边、角以及 缺陷也能有效提升催化性能. 还可以采用Pt纳米粒子结合其它金属元素形成双金属合金, 如, Pt-M (M = Pd, Au, Ag, Ru, Fe, $\mathrm{Co}, \mathrm{Ni}$, 等)催化剂, 可以在减少Pt元素用量的同时有效提升催化活性. 在众多可供选择的元素中, Pd相对于Pt价格低廉, 但 两者具有相近的物理、化学性质以及较高的电催化性能, 使Pt-Pd纳米合金呈现十分优异的电催化性能. 研究表明, Pt-Pd纳 米合金在酸性和 $\mathrm{CO}$ 环境中能有效催化有机小分子电氧化过程. 另外, 在酸性环境中, 用 $\mathrm{Pd}$ 替代Cu, $\mathrm{Ag}, \mathrm{Co}$ 或 $\mathrm{Ni}$, 可以有效 减少催化剂的腐蚀.

本文在乙二醇溶液中同时还原 $\mathrm{K}_{2} \mathrm{PtCl}_{4}$ 和 $\mathrm{Na}_{2} \mathrm{PdCl}_{4}$, 在 $110{ }^{\circ} \mathrm{C}$ 反应 $5 \mathrm{~h}$ 制备出超细的Pt-Pd纳米合金. 通过 $\mathrm{X}$ 射线衍射 (XRD)、透射电子显微镜(TEM)、高分辨透射电子显微镜(HRTEM)以及能谱仪(EDS)对合金进行表征, 从而确定产物为尺 寸 $4 \mathrm{~nm}$ 左右的Pt-Pd纳米合金, 且通过改变金属前驱体的投料比可以有效调控Pt-Pd合金组分(按元素比例分别表示为 Pt1Pd3, Pt1Pd1, Pt3Pd1). 采用循环伏安法、线性扫描伏安法以及计时安培法等多种手段测试样品在 $0.5 \mathrm{~mol} / \mathrm{L} \mathrm{H}_{2} \mathrm{SO}_{4}$ 和 0.5 $\mathrm{mol} / \mathrm{L} \mathrm{CH}_{3} \mathrm{OH}$ 的酸性环境中 $(50 \mathrm{mV} / \mathrm{s})$ 电化学性能, 并与商业 $\mathrm{Pt} / \mathrm{C}$ 进行比较. 结果表明, 合金的催化性能和组分密切相关, 当 
Pt元素的含量为 $75 \%$ 左右时, Pt-Pd纳米合金表现出最佳的催化活性和稳定性, 其中 $\mathrm{Pt}_{3} \mathrm{Pd}_{1}$ 的电催化质量活性可达商业Pt/C的 7倍之多. 我们把Pt-Pd纳米合金的催化性能对其组分的依赖性归结为甲醇氧化反应中的双官能团机制, 反应中, Pt可有效 催化甲醇脱氢产生Pt-CO, Pd则催化水脱氢形成Pd-OH. 当Pd含量减少时, Pt表面的水脱氢反应只有在高电位才能发生, 从 而降低催化效率; 而Pd含量过多, 则会抑制Pt催化甲醇的脱氢反应, 使催化效率大大降低. 因此, 只有适宜Pt/Pd比例, 才能 有效提升催化效率.

关键词: 铂钯纳米合金; 组分和尺寸可控; 甲醇氧化

收稿日期: 2017-09-20. 接受日期: 2017-12-27. 出版日期: 2018-02-05.

*通讯联系人.电话: (0731)88879341; 传真: (0731)88876692; 电子信箱: qiwh216@csu.edu.cn

基金来源：国家自然科学基金(21373273).

本文的电子版全文由Elsevier出版社在ScienceDirect上出版(http://www.sciencedirect.com/science/journal/18722067).

\section{《催化学报》为被国际期刊退稿的高质量论文开辟绿色通道}

我们注意到, 国内一些高质量、原创性的研究工作在投稿到国际期刊上时, 经常因语言和写作问题等非科 学因素而被退稿和拖延发表, 甚至会失去原创知识产权, 这个损失是巨大的, 也是非常可惜的!

众所周知, 按国际学术界的共识, 获得论文的首发权并保证拥有研究工作的原创性不在于论文发表在哪个 刊物(只要是国际ISSN挂号的), 而在于谁第一时间抢先发表了工作.

为了保护作者工作的原创性和首发知识产权, 《催化学报》编委会为具有一定原创性的论文提供快速发表 的绿色通道. 对于投到国际著名期刊(如Science, Nature, Energy \& Environmental Science, Journal of the American Chemical Society, Angewandte Chemie International Edition, ACS Catalysis和Journal of Catalysis等)上催化论 文的退稿, 如果其创新性较强, 学术质量较高, 仅仅是因为语言和文章写作原因而被退稿, 《催化学报》会安排 其在最近一期上抢时间发表; 如果文章原创性较好, 不存在学风问题, 但有一些理论观点的争议、实验现象暂 时无法得到完美的理论解释, 或者需要进一步补充相关实验数据等, 本刊主编、副主编也会协助作者尽快修改 和发表相关工作.

对于国际著名相关期刊的退稿, 作者需将相应的审稿意见及意见答复等材料一并提交到本刊, 以加快论文 的处理速度. 